\title{
Patterns of seagrass macrobenthic biodiversity in the warm- temperate Knysna estuarine bay, Western Cape: a review
}

\author{
R. S. K. Barnes $\mathbb{B}$
}

Received: 3 December 2020 / Accepted: 24 February 2021 / Published online: 11 March 2021

(C) The Author(s) 2021

\begin{abstract}
Knysna estuarine bay in South Africa's Garden Route National Park is that country's most significant estuarine system for biodiversity and conservation value. One outstanding feature is support of $40 \%$ of South Africa's - and maybe $20 \%$ of the world's—remaining vulnerable and decreasing dwarfeelgrass, Zostera capensis, whose associated benthic macrofauna has been studied since 2009. For these invertebrates, Knysna comprises several significantly different compartments: sandy mouth; well-flushed marine embayment; poorly flushed central sea-water 'lagoon'; and two disjunct but faunistically similar peripheral regions-marine backwater channels, and low-salinity upper estuary. Although macrofauna ranges from dilute brackish to fully marine, its abundance, local patchiness, and over considerable stretches, species density remains remarkably
\end{abstract}

Handling Editor: Télesphore Sime-Ngando

R. S. K. Barnes $(\bowtie)$

Department of Zoology and Entomology, Rhodes

University, Eastern Cape, Makhanda 6140, Republic of

South Africa

e-mail: rsb1001@cam.ac.uk

R. S. K. Barnes

Knysna Basin Project Laboratory, Western Cape,

Knysna 6571, Republic of South Africa

R. S. K. Barnes

Department of Zoology and Conservation Research

Institute, University of Cambridge, Cambridge, UK constant; further, one-third of species occur throughout. Intertidally, all but peripheral compartments are low density and infaunally dominated, while some peripheral areas, and much of the subtidal, are higher density and epifaunally dominated. Overall, seagrass macrobenthos appears maintained below carrying capacity (e.g., by abundant juvenile fish) and of random species composition within a site. Two further characteristics are notable: Unusually, seagrass supports fewer animals than adjacent unvegetated areas, probably because of lack of bioturbatory disturbance in them, and the vegetation cover may ameliorate ambient habitat conditions. Unfortunately, continual heavy and effectively unpreventable exploitation for bait occurs, and chlorophyte blooms have developed because of high nutrient input. Knysna presents a microcosm of problems facing biodiverse and highvalue habitats set within areas of high unemployment where subsistence fishing provides the main source of protein and seagrass provides the only source of bait.

Keywords Biodiversity · Conservation - Intertidal · Knysna $\cdot$ Macrobenthos $\cdot$ Seagrass

\section{Introduction}

The permanently open Knysna estuarine bay $\left(34^{\circ} 03^{\prime} \mathrm{S}\right.$, $23^{\circ} 03^{\prime} \mathrm{E}$ ) is a drowned river valley in South Africa's 
Western Cape separated from the adjacent Indian Ocean by a narrow gorge (300 m wide, $700 \mathrm{~m}$ long, and $4 \mathrm{~m}$ deep at low tide) carved through the coastal quartzite ridge by the Knysna River during times of lower sea level. The bay forms part of the open-access Garden Route National Park, and on a basket of criteria, including its size, diversity of habitat, zonal rarity, and biodiversity, is ranked South Africa's most significant estuarine system in terms of conservation importance (Turpie and Clark 2007; van Niekerk et al. 2019). Known locally as the Knysna Lagoon, the system has an area of some $10 \mathrm{~km}^{2}$ at low tide and 16 $\mathrm{km}^{2}$ at high tide and receives the inflow of the Knysna River at its head and a large number of smaller streams along its northern and eastern shores. Nevertheless, it is marine-dominated, consequent on low average rates of freshwater inflow and a very large tidal prism, during spring tides equaling $19 \times 10^{6} \mathrm{~m}^{3}$ [the largest of any South African estuary (Grindley 1985)], causing semi-diurnal flushing of its main channel. The estuarine bay can be divided hydrologically into three linear compartments, which vary in areal extent and precise geographical position with the tidal cycle and magnitude of river flow: An outer marine bay tidally flushed with cool water from the Indian Ocean and with salinities usually $>34$; a middle, more isolated lagoonal water body also of high salinity (30-34) but with long residence times (c. 4 weeks); and an inner, stratified and well-flushed estuarine region with low and variable salinity $(0-30)$ as a result of freshwater input from the Knysna River (Largier et al. 2000).

This system is also one of the most thoroughly researched of any South African estuary with more than 100 published articles (Russell et al. 2012; Whitfield and Baliwe 2013), work there beginning in 1947 (Day et al. 1951) (see the summaries of Day 1967; Grindley 1985; Russell et al. 2012; and the articles in Hodgson and Allanson 2000). Among other important features, Knysna supports $40 \%$ of South Africa's dwarf-eelgrass, Zostera (Zosterella) capensis [or Nanozostera capensis in the recent revision of the Zosteraceae of Coyer et al. (2013)] which may equate to $20 \%$ of its world area (Adams 2016; Wasserman et al. 2020). It also forms the only known African locality of the unusual marine valvatoidean gastropod Cornirostra (GBIF 2020), as well as being the main habitat of several other rare seagrass-associated species, including the endangered Knysna seahorse
(Hippocampus capensis), and it is one of the only two localities that support the critically endangered seagrass false-limpet (Siphonaria compressa) and a seagrass population of the dwarf cushion-star Parvulastra exigua. Except in the immediate vicinity of the mouth, Z. capensis, together with some mixed Halophila ovalis, occurs virtually throughout the intertidal zone of the system as one continuous bed (Maree 2000), and it also occurs subtidally though more patchily (Wasserman et al. 2020; Barnes and Claassens 2020). Such meadows support well-developed invertebrate macrofaunas that serve the vital functions of consuming epiphytic algal growths and providing the trophic link between microphytobenthic production and that of the larger, more mobile nekton (Murphy et al. 2021). This article synthesizes the main findings of the disparate series of researches conducted on these invertebrate faunal assemblages at Knysna since 2009, re-analyzing the original data where appropriate, with particular emphasis on patterns of macrofaunal assemblage composition, abundance, species richness, and patchiness along the bay's main axial transitional gradient, as well as along the gradient of shelter, located perpendicular to that axis across its eastern section.

\section{General methodology}

Patterns described in this review are based mainly on a series of 23 sites positioned to represent the whole area over which Zostera capensis is present intertidally (Fig. 1), with additional comparison between the macrofaunal eelgrass assemblages at some of those sites and the equivalent assemblages in immediately adjacent areas of bare sediment and/or in subtidal seagrass. Sampling was conducted each year between 2009 and 2020 during the austral summer, the research being approved by SANParks and conducted in accordance with their scientific research regulations and requirements. A standard procedure was used, involving series of core samples, each of $0.0027 \mathrm{~m}^{2}$ diameter prior to 2013 and of $0.0054 \mathrm{~m}^{2}$ diameter thereafter and of $100 \mathrm{~mm}$ depth, taken from continuous stretches of seagrass while still covered by $>10$ $\mathrm{cm}$ of water. Cores were gently sieved ('puddled') through $710-\mu \mathrm{m}$ mesh on site. This sampling procedure collects the smaller and more numerous members of the benthic and epibenthic macrofauna that 


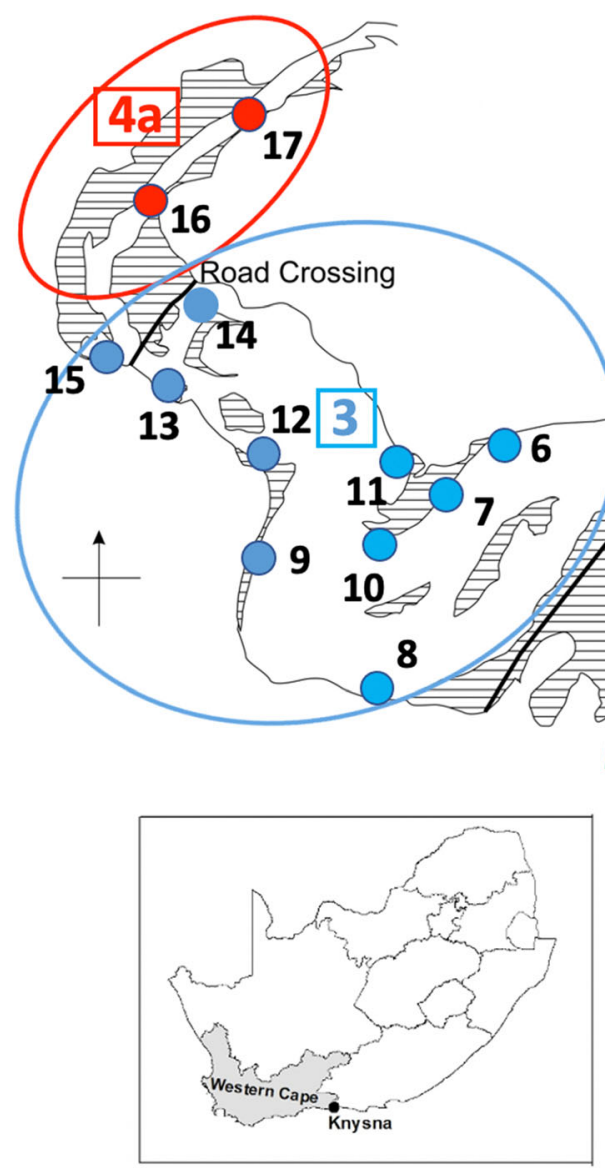

Fig. 1 Knysna estuarine bay, showing location of the linear chain of 17 sampling sites along its longitudinal axis and of the six sites a-f set within the backwaters of the Ashmead and

constitute the large majority of invertebrate biodiversity (Bouchet et al. 2002; Albano et al. 2011), though not the meiofauna nor much scarcer megafauna nor sessile animals attached to the seagrass leaves.

In the laboratory, retained animals from each core were identified to species level wherever possible, with all organismal nomenclature here being as listed in the World Register of Marine Species (www. marinespecies.org), accessed November 2020, except in respect of the currently genus-less microgastropods 'Assiminea' capensis and 'A'. globulus (see Barnes 2017). It should be noted, however, that the specific identity of several animals, especially among the Polychaeta, is questionable because of lack of recent revision; those of South African taxa of Polycladida, Oligochaeta, and Nemertini, and many members of other groups less than $3 \mathrm{~mm}-4 \mathrm{~mm}$ in largest

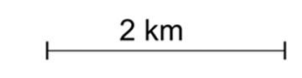




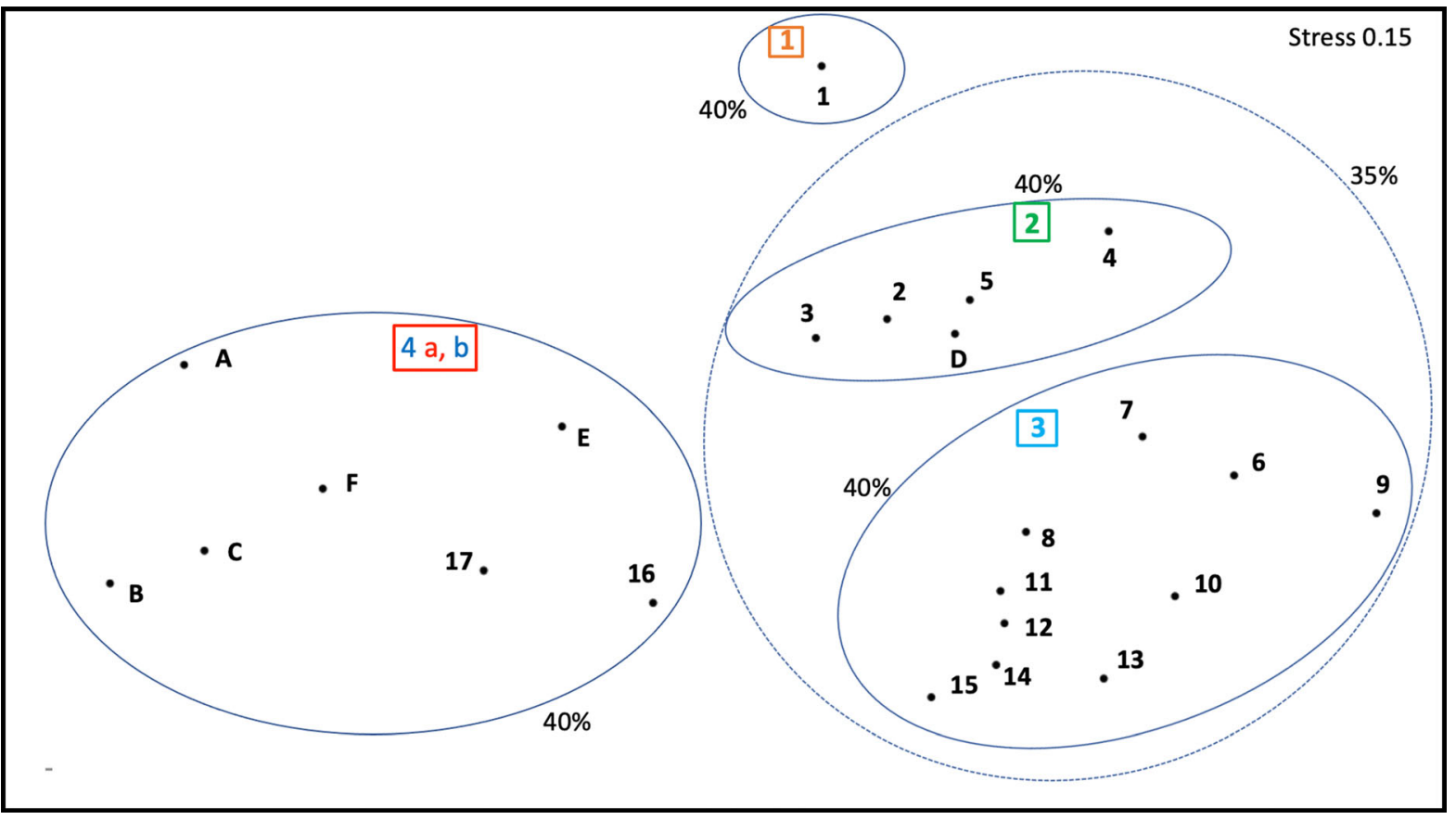

Fig. 2 nMDS plot based on Bray-Curtis similarities between percentage species composition data at the 23 sites, showing the four groups of seagrass macrofaunal assemblage types, i.e., those in: a the sandy mouth region; $\mathbf{b}$ the marine bay; $\mathbf{c}$ the lagoon and lower estuary; and $\mathbf{d}$ the upper estuary and the marine-basin backwater channels. The boundary between

statistically significant departures from random being determined by Monte Carlo simulation using 9999 iterations. Correlations were assessed using Spearman's rank coefficient $S_{\rho}$ or the Pearson productmoment coefficient $P_{\rho}$ as appropriate; number of species per site unit of 30 cores and per region unit of 180 cores was determined by Mao tau rarefaction; curves were fitted using KaleidaGraph 4.5.4; and, where not known, information on life style of individual species was derived from that of close relatives in compendia such as Macdonald et al. (2010).

Multivariate comparison of macrofaunal assemblage composition used hierarchical clustering analysis of $\mathrm{S}_{17}$ Bray-Curtis similarity, ANOSIM, ANCOVA, SIMPER, and ordination by non-metric multidimensional scaling (nMDS), with 9999 permutations. For such comparison, all data sets were standardized for overall species density (by dividing all ranks by the total number of species in the set) and for sample size (by dividing each species total by the overall number of individuals in the set) to reflect backwaters and axial channel conditions in the marine section would appear to lie along the Steenbok Channel in that site D falls within one grouping and $\mathrm{E}$ in the other. Envelopes enclose sites with the stated levels of Bray-Curtis similarity, for which the approximate geographical locations are shown in Fig. 1

solely differential taxonomic composition and to permit comparison of curve slopes (Passy 2016), a measure of equitability in individual species contribution to the total (Whittaker 1972). Overlaps in quantitative assemblage composition between adjacent regions were measured by the Bray-Curtis similarity index. All multivariate analyses were based on sample sizes of $>250$ animals, well above the minimum number recommended by Forcino et al. (2015).

\section{Principal findings}

Patterns in assemblage composition

In total, some 67,000 individual macrofauna, representing 160 species, were examined in 2,100 core samples from the Zostera beds during the study. These ranged from typical freshwater/dilute-brackish species such as Afrochiltonia capensis, Corallana africana and Melanoides tuberculata through to fully marine 

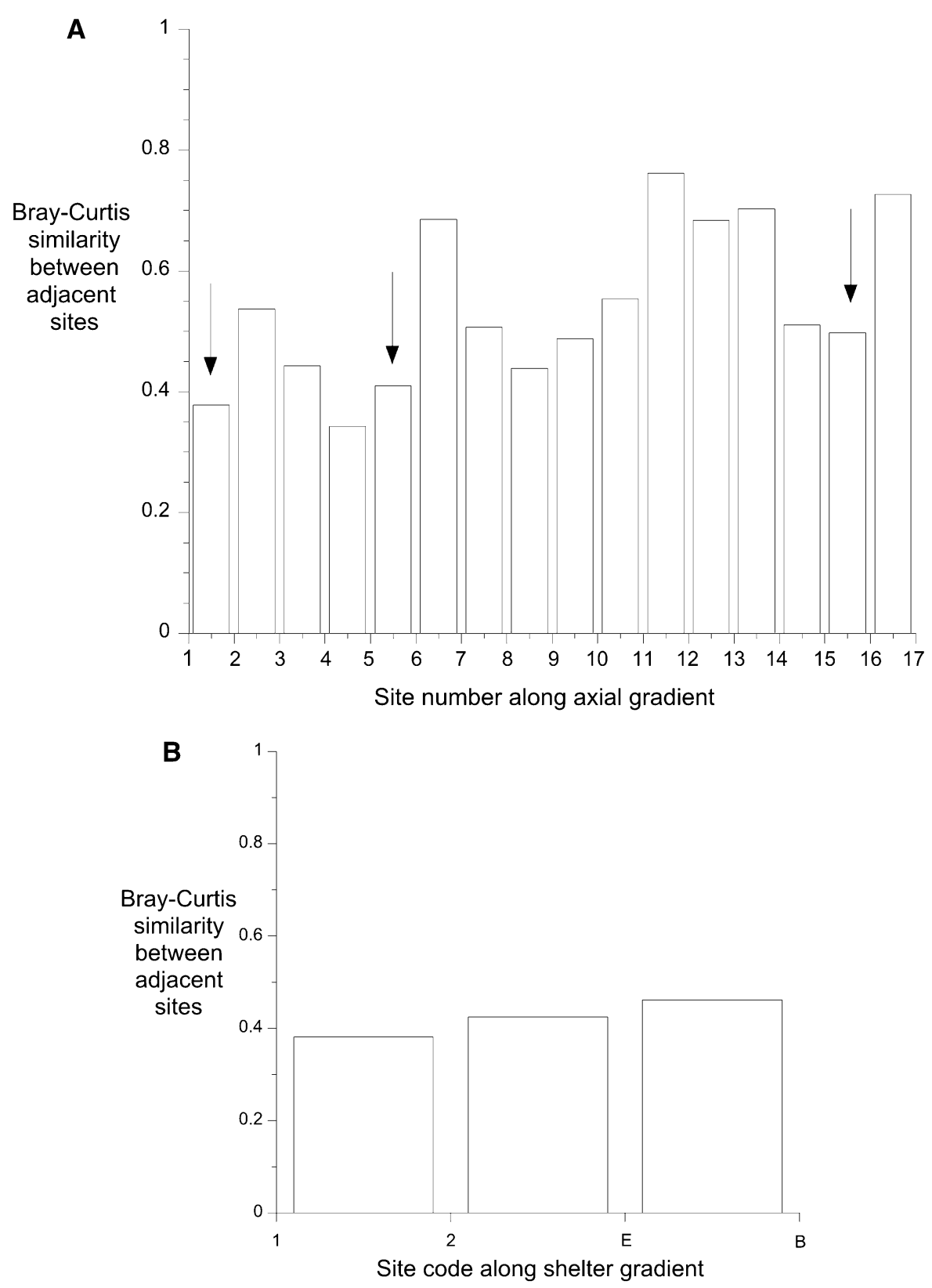

Fig. 3 Levels of Bray-Curtis similarity between the seagrass macrofaunal assemblages of adjacent sites: a along the longitudinal axis of the estuarine bay (arrows indicating points of transition between adjacent faunal assemblage types shown in

forms such as Gibbula cicer, Limaria tuberculata, Nebalia capensis and Parechinus angulosus. Ordination by nMDS of Bray-Curtis similarity data from the 23 intertidal sites suggested that four significantly different faunal clusters occurred in the system (ANOSIM R $=0.88 ; P<0.0001$ ) (Figs. 1and 2), an
Fig. 2), and $\mathbf{b}$ along the axis of shelter perpendicular to 'A' from the main channel into the fringing backwaters of the marine embayment

essentially similar pattern to that derived earlier using non-standardized (but fourth-root transformed) abundance data (Barnes 2013a). These represented: (i) the sandy mouth region immediately adjacent to the true mouth, (ii) the outer marine embayment, and (iii) the lagoon plus lower-estuary divisions of the main axial 
Table 1 The more dominant members of the Knysna intertidal seagrass macrofauna present in all four significantly different compartments of the system. These 21 species together comprise $70 \%$ of the total macrofaunal individuals sampled

\begin{tabular}{ll}
\hline GASTROPODA & Capitella sp. \\
'Assiminea' capensis & Orbinia angrapequensis \\
Nassarius kraussianus & Cirriformia sp. \\
Alaba pinnae & Paradoneis lyra capensis \\
Turritella capensis & PERACARIDA \\
BIVALVIA & Exosphaeroma hylecoetes \\
Arcuatula capensis & Melita zeylanica \\
Salmacoma litoralis & Grandidierella lutosa \\
OLIGOCHAETA & Cymadusa filosa \\
tubificid sp. & BRACHYURA \\
POLYCHAETA & Danielella edwardsii \\
Simplisetia erythraeensis & Hymenosoma orbiculare \\
Prionospio sexoculata & OSTRACODA \\
Caulleriella capensis & ?Cylindroleberis sp. \\
\hline
\end{tabular}

channel, and (iv) the fringing backwater-creek system of the smaller, saltmarsh-enclosed creeks and channels that separate the bay's two large islands (each $c$. 82-84 ha) from the mainland, together with sites in the upper estuary. Separation of the backwaters/upperestuary sites from those along the main axial channel was the most marked, with a Bray-Curtis similarity between the two blocks of sites of only $20 \%$, and the mouth region was an outlier within the axial channel. The three points of change along the longitudinal axis of the bay, however, were not marked by sharp faunal contrasts (Fig. 3). Indeed, SIMPER indicates that most $(>50 \%)$ of the differences are brought about by the relative abundances of just eight common and widespread species, the gastropod molluscs Hydrobia knysnaensis and 'Assiminea' capensis (dominant in region iv), Turritella and Alaba (dominant in i), and Nassarius (dominant in iii), and the polychaetes Prionospio (dominant in iii), and Caulleriella and Simplisetia (dominant in ii). Despite statistically significant regionalization, $32 \%$ of the species (representing $>75 \%$ of the total individuals) occurred in all four regions in more than token quantities (Table 1 lists the more numerous of these shared taxa, and Table 2 displays those characteristic of each region). Patterns of relative species abundance within the four regions did not differ (ANCOVA equality of means $F=0.17, \quad P=0.92$; equality of slopes $F=0.59$,
$P=0.62$ ) (Fig. 4), further indicating similarity between the different local assemblages. Number of species per sample did not vary across test areas of up to 1.5 ha at a given site, whether in the bay or in the lagoon (Table 3). The observation that the seagrass macrofauna of the brackish upper estuary did not differ from that in the fully saline, saltmarsh-enclosed backwater channels of the marine embayment is noteworthy and reinforces the earlier comments of Day (1959) and Barnes (1989) that so-called estuarine faunas may be as characteristic of sheltered areas of fully marine soft sediment as they are of regions subject to low salinity.

Major differences, however, did occur in the relative importance of infauna versus epifauna. Except at the lagoonal site 9, where the small biofilm-feeding cushion star Parvulastra exigua occurs in large numbers, the intertidal zone of the whole axial channel apart from the upper estuary is dominated by infaunal species (Fig. 5a), principally by polychaetes. From sites 1 to 15, the infauna comprised 68\% (SE 3.7) of animals with no significant trend in their relative importance along the gradient $\left(S_{\rho}=0.31 ; P=0.26\right)$ (Fig. 5B). In contrast, the shores of the upper estuary and the marine backwater channels were dominated by epifaunal truncatelloid microgastropods, especially by 'Assiminea' capensis and Hydrobia knysnaensis, epifauna here comprising $64.4 \%$ of individuals. Only a few subtidal $Z$. capensis sites have so far been examined, but such areas are also overwhelmingly dominated by an epifaunal microgastropod, here by the cerithioid Alaba pinnae, although the importance of this species and hence of the subtidal epifauna in general decreases upstream so that epifauna and infauna contribute equally in the upper estuary (Fig. 5a). Thus in the bay region there is a transition at some LWS between a burrowing polychaete infauna and a seagrass-leaf-associated gastropod epifauna, and although upstream sub- and intertidal faunas are relatively similar, downstream in the bay they are markedly different (Fig. 6a). Few data are available to help explain the great downstream subtidal abundance of the epifaunal Alaba (a mean density of $28,000 \mathrm{~m}^{-2}$ ), although various studies have suggested that few fish consume significant numbers of shelled gastropods, even relatively small ones (McCormick 1998; Reynolds et al. 2018), not least because of their low nutritive value per unit intake (Vinson and Baker 2008). It is known that in South Africa, mugilids will 
Table 2 Characteristic intertidal seagrass macrofauna (i.e., those together comprising $75 \%$ of the faunal individuals) of the four significantly different faunal regions of the Knysna estuarine bay

\begin{tabular}{|c|c|c|c|}
\hline Species & $\%$ & Species & $\%$ \\
\hline Mouth sandflats & & Marine bay & \\
\hline Alaba pinnae & 21.4 & Simplisetia erythraeensis & 17.8 \\
\hline Turritella capensis & 13.5 & Prionospio sexoculata & 11.1 \\
\hline Simplisetia erythraeensis & 9.8 & Caulleriella capensis & 8.9 \\
\hline ?Cylindroleberis $\mathrm{sp}$ & 7.1 & Exosphaeroma hylecoetes & 4.5 \\
\hline Orbinia angrapequensis & 4.3 & Nassarius kraussianus & 3.6 \\
\hline Paradoneis lyra capensis & 3.6 & Melita zeylanica & 3.5 \\
\hline Pseudopolydora ?kempi & 2.9 & Hymenosoma orbiculare & 3.4 \\
\hline Diogenes brevirostris & 2.9 & Danielella edwardsii & 3.4 \\
\hline Caulleriella capensis & 2.7 & Cyathura estuaria & 3.1 \\
\hline Nassarius kraussianus & 2.6 & Grandidierella lutosa & 2.4 \\
\hline Paridotea ungulata & 1.9 & Cymadusa filosa & 2.4 \\
\hline Grandidierella lutosa & 1.8 & Arcuatula capensis & 2.3 \\
\hline Lagoon + lower estuary & & tubificid sp. & 2.1 \\
\hline Prionospio sexoculata & 27.3 & ?Cylindroleberis sp. & 2.0 \\
\hline Nassarius kraussianus & 15.6 & Paramoera capensis & 1.9 \\
\hline Arcuatula capensis & 10.7 & 'Assiminea' capensis & 1.6 \\
\hline Parvulastra exigua & 6.0 & Alaba pinnae & 1.5 \\
\hline Simplisetia erythraeensis & 5.3 & Backwater channels + upper estuary & \\
\hline Salmacoma litoralis & 5.2 & 'Assiminea' capensis & 40.0 \\
\hline Cirriformia sp. & 2.9 & Hydrobia knysnaensis & 27.3 \\
\hline \multirow[t]{2}{*}{ Dosinia hepatica } & 2.7 & Halmyrapseudes cooperi & 4.1 \\
\hline & & Simplisetia erythraeensis & 3.7 \\
\hline
\end{tabular}

take microgastropods (Whitfield and Blaber 1978; Whitfield 1988), but at Knysna mugilids do not characterize the dense sublittoral eelgrass beds favored by Alaba (Pollard et al. 2017). Several equivalent subtidal areas of seagrass in other continents are also dominated by species of Alaba, although Knysna is the only known such locality outside the tropics (Barnes and Claassens 2020). These other areas are of relatively high salinity which may help to account for the lesser importance of this gastropod in and near the upper estuary. Why the same suite of truncatelloid microgastropods dominates the otherwise contrasting habitats of the intertidal backwaters and upper estuary is not known for certain, but their common shelter (see paragraph above) is likely to be an important component.

With one exception, no evidence of any strong species interactions within any given site was forthcoming. The exception was the positive correlation between numbers of the ectoparasitic pyramidellid snail Sayella sp. and those of its probable host
Hydrobia at the backwater site 'A' in Fig. $1\left(R_{\mathrm{S}-}\right.$ $=0.78 ; P<0.00001)$. Such a parasite/host association is known from the western Atlantic (e.g., Hershler and Davis 1980), but although the pyramidellid concerned is a widely distributed animal, it is otherwise not recorded from Africa (GBIF 2020). That exception apart, however, in a large sample (325 cores) from the Kingfisher Creek seagrass (site 2 in Fig. 1), for example, Barnes (2013b) recorded 75 macrofaunal species at overall and mean densities of 2581 and $34 \mathrm{~m}^{-2}$, respectively. Considering the 34 relatively common species there that each attained a mean density of at least $10 \mathrm{~m}^{-2}$ (and together comprised $96 \%$ of the total individuals), all pairwise correlations of species abundance were very weak to non-existent (sensu Moore et al. 2018), positives averaging only $P_{\rho}=0.069$ ( $\left.\pm 0.060 \mathrm{SD}\right)$ and negatives $P_{\rho}=0.047$ ( $\pm 0.035 \mathrm{SD}$ ); and allowing for the familywise errors inherent in such a large correlation matrix (via Bonferroni correction), no negative correlations and only three positive ones were significant at 


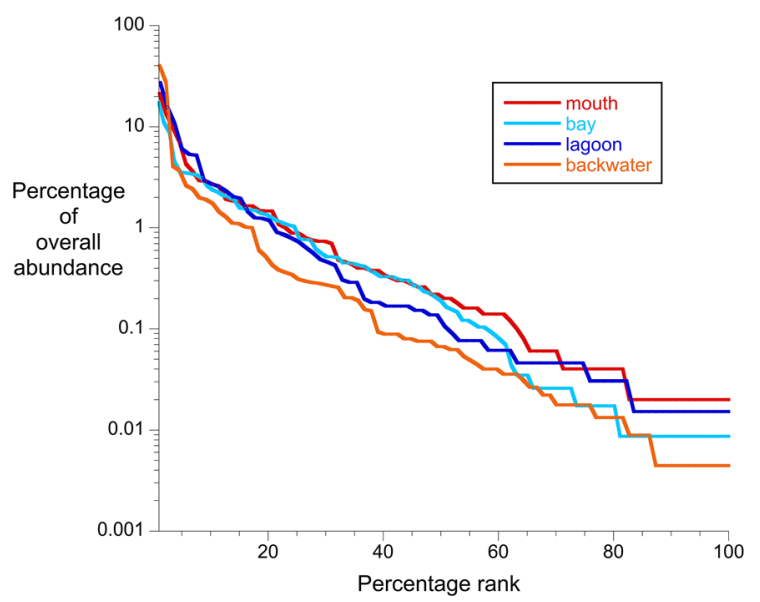

Fig. 4 Species abundance diagrams (Whittaker plots) for each of the four faunistically distinct assemblage types

Table 3 Uniformity of number of intertidal species per sample at different scales across test areas of (A) 0.2 ha and (B) 1.5 ha at Site 2 and (C) along a $350 \mathrm{~m}$ transect at site 9 , as assessed by Lloyd's index of patchiness $\left(I_{\mathrm{p}}\right)$ and the Azovsky et al. (2000)

\begin{tabular}{llll}
\hline Unit sample size & Lloyd's $I_{\mathrm{p}}$ & Azovsky et al.'s $I_{\mathrm{a}}$ & Significance of uniformity \\
\hline $\mathrm{A}$ & & & $P=0.1$ \\
$0.0015 \mathrm{~m}^{2}$ & 0.948 & 0.977 & $P=0.03$ \\
$0.0027 \mathrm{~m}^{2}$ & 0.938 & 0.988 & $P=0.004$ \\
$0.0054 \mathrm{~m}^{2}$ & 0.933 & 0.995 & $P=0.009$ \\
0.0095 & 0.962 & 0.995 & $P=0.005$ \\
$\mathrm{~B}$ & & 0.997 & $P=0.01$ \\
$0.0054 \mathrm{~m}^{2}$ & 0.974 & & 0.994 \\
$\mathrm{C}$ & & 0.929 &
\end{tabular}

index of spatial homogeneity $\left(I_{a}\right)$, with significance of $I_{\mathrm{p}}$ tested by Monte Carlo simulation (data from Barnes, 2013b, 2016 and Barnes and Hendy, 2015a) a critical $\alpha$ of $<0.05$ (between the polychaetes Simplisetia and Caulleriella, Glycera and Cirriformia, and between the polychaete Prionospio and the gastropod Nassarius). Equivalently, although qualitative co-occurrence patterns across the whole of the marine-influenced embayment at Knysna show deterministic structuring (Barnes and Elwood 2011), as indeed might be expected granted the location of the sampled sites in three distinct faunal regions (sandy mouth, marine bay, and backwater system), syntopic species within a single one of those regions did not differ from random co-occurrences (Barnes and Barnes 2014b).

In the absence of strong bioturbators such as Kraussillichirus kraussi (Callianassa kraussi in the older literature) from the majority of the system, faunal relationships between seagrass and bare sediment at Knysna are not the classic one of seagrass supporting the greater number of species and of individuals per unit area (Hemminga and Duarte 2000; Pillay et al. 2011; Hyman et al. 2019, etc.). To date studies have only concerned the outer marine embayment, but there seagrass macrofauna at a given site is more similar to those occurring in adjacent areas of bare sediment than either habitat is to other areas of the same type in the general region [Bray-Curtis faunal similarity between the two contiguous habitat types being a mean 0.58 , whereas within-habitat-type similarity averaged 0.26 for the seagrass and 0.25 for the bare sediment (ANOVA $\left.F_{1,14}=5.05 ; P<0.05\right)$ ] (see 

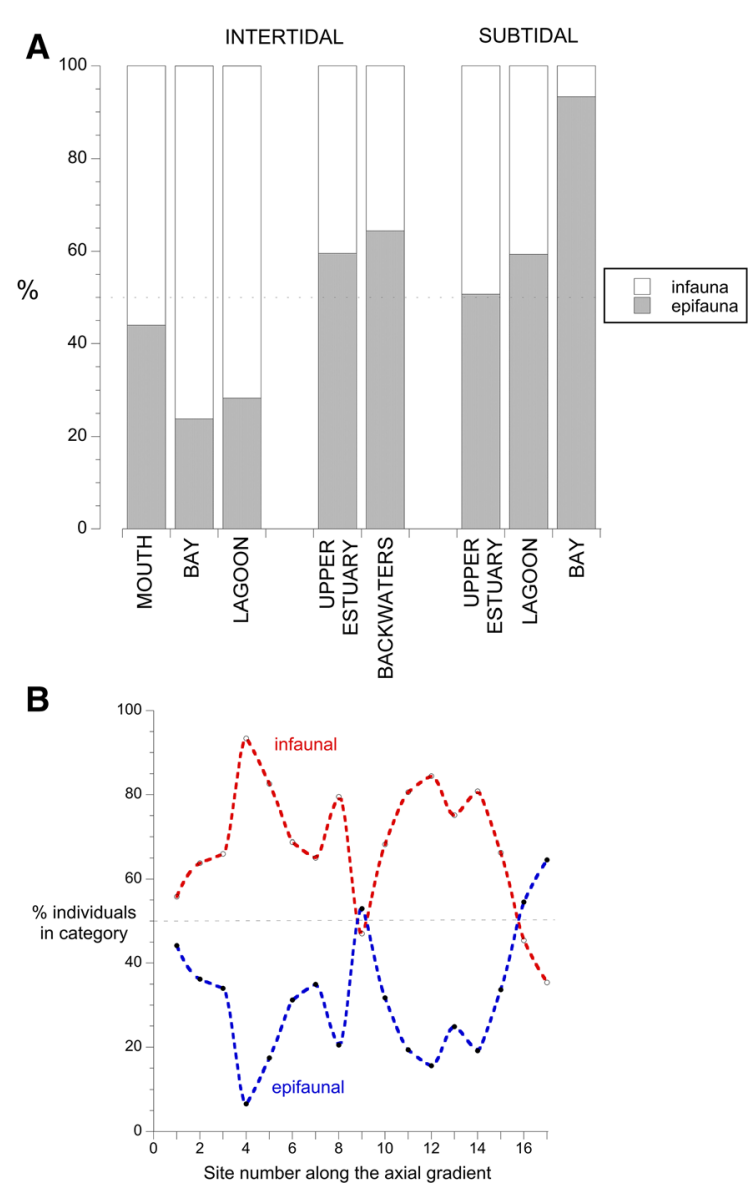

Fig. 5 Relative importance of infauna and epifauna in a the different intertidal and subtidal regions of the estuarine bay and $\mathbf{b}$ at each of the sites along the longitudinal axial channel

Fig. 6b). In general, seagrass beds supported lower, not higher, levels in half the metric comparisons in which there was a significant difference (Barnes and Barnes 2014a). Overall, faunal abundance was lower in seagrass in the ratio of $0.64: 1$, while species density was indeed higher, but only by 1.13 to 1 , with in large measure the higher numbers in the unvegetated sediments resulting from a quadrupled abundance of infaunal polychaetes, maybe because of the greater volume of available sedimentary habitat in the absence of eelgrass rootmass, although numbers of epifaunal crustaceans were 15 times less there (from a much smaller base). The same overall effect was not the case, however, in bare areas created by the death of seagrass following blanketing by the chlorophyte blooms described by Allanson et al. (2016) and
Human et al. (2016). In these circumstances, the former seagrass sites clustered together, as did the same areas when de-vegetated, although macrofaunal abundance was again significantly lower in the former seagrass than it was in the replacement bare sediment (in a ratio of 0.62: 1) and again largely because of an increased number of polychaetes and decreased number of crustaceans in the unvegetated sediment (Barnes 2019a).

Knysna's marine embayment forms a natural harbor, has been in the past a busy port (Grindley 1985), and today supports several marinas, and hence it is one of the centers of ship-borne alien immigrant species in South Africa (Griffiths et al. 2009). Alien species of Boccardia, Polydora, Dipolydora, Pseudopolydora, Diopatra, Capitella, Desdemona, Ericthonius, Jassa, Monocorophium, Paracerceis, Elysia, Favorinus and Indothais all form part of its seagrass fauna, as do amphipods such as Cymadusa filosa, Melita zeylanica and Americorophium triaeonyx that are regarded by Robinson et al. (2005) and Mead et al. (2011) as being cryptogenic - to which could presumably be added Victoriopisa chilkensis. Relatively recently, these aliens have been joined by more northerly species spreading southward probably as a result of global warming. Smaragdia souverbiana, for example, is now a member of the subtidal seagrass fauna (Barnes and Claassens 2020). In the Knysna intertidal, Melanoides tuberculata has arrived and joined Cerithidea decollata (Hodgson and Dickens 2012) and Austruca occidentalis (formerly Uca annulipes) (Peer et al. 2015), the latter two in the adjacent saltmarsh or at the seagrass/saltmarsh interface.

Patterns in assemblage metrics along the axial gradient

As would be expected, the number of species at the 17 sites that were spaced along the system's longitudinal axis decreased with distance upstream $\left(S_{\rho}=-0.82\right.$; $P<0.0001$; Fig. 7a), but the form of the decrease in species density suggests the occurrence of a step change within the general area of the lower estuary, with the downstream sites showing a considerable degree of uniformity of species density (Fig. 7b; Table 4). The points in Fig. 7 are based on the whole available 12-year dataset, and hence, the location of faunal and regional boundaries will have been blurred 
A

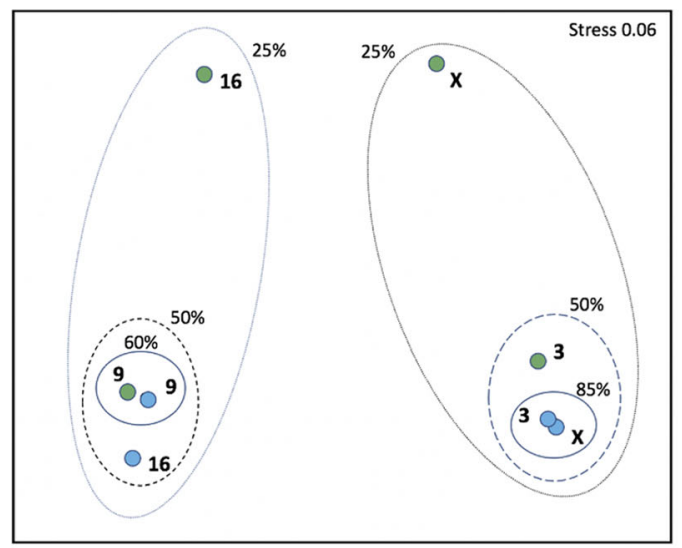

Fig. 6 nMDS plots based on Bray-Curtis similarities between percentage species composition data: a at four sites in the Knysna estuarine bay, one in each faunal compartment, showing the similarity between macrofaunal assemblages of seagrass at LWS in the intertidal zone and in the adjacent subtidal area (from data in Barnes and Claassens 2020), and $\mathbf{b}$ at three sites in the marine embayment forming a transect from the main

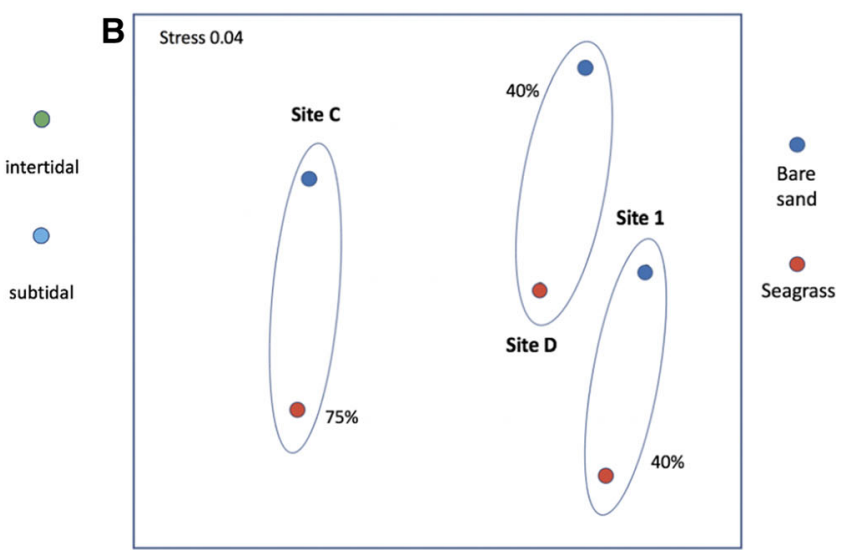

channel (site 1) into the backwater Steenbok Channel and its tributaries, showing similarity between macrofaunal assemblages in seagrass and in adjacent areas of bare sediment (from data in Barnes and Barnes 2014a). Envelopes enclose sites at the stated levels of Bray-Curtis similarity, and site codes are those given in Fig. 1, plus in (A) an additional site, ' $\mathrm{X}$ ', located between sites 1 and 2
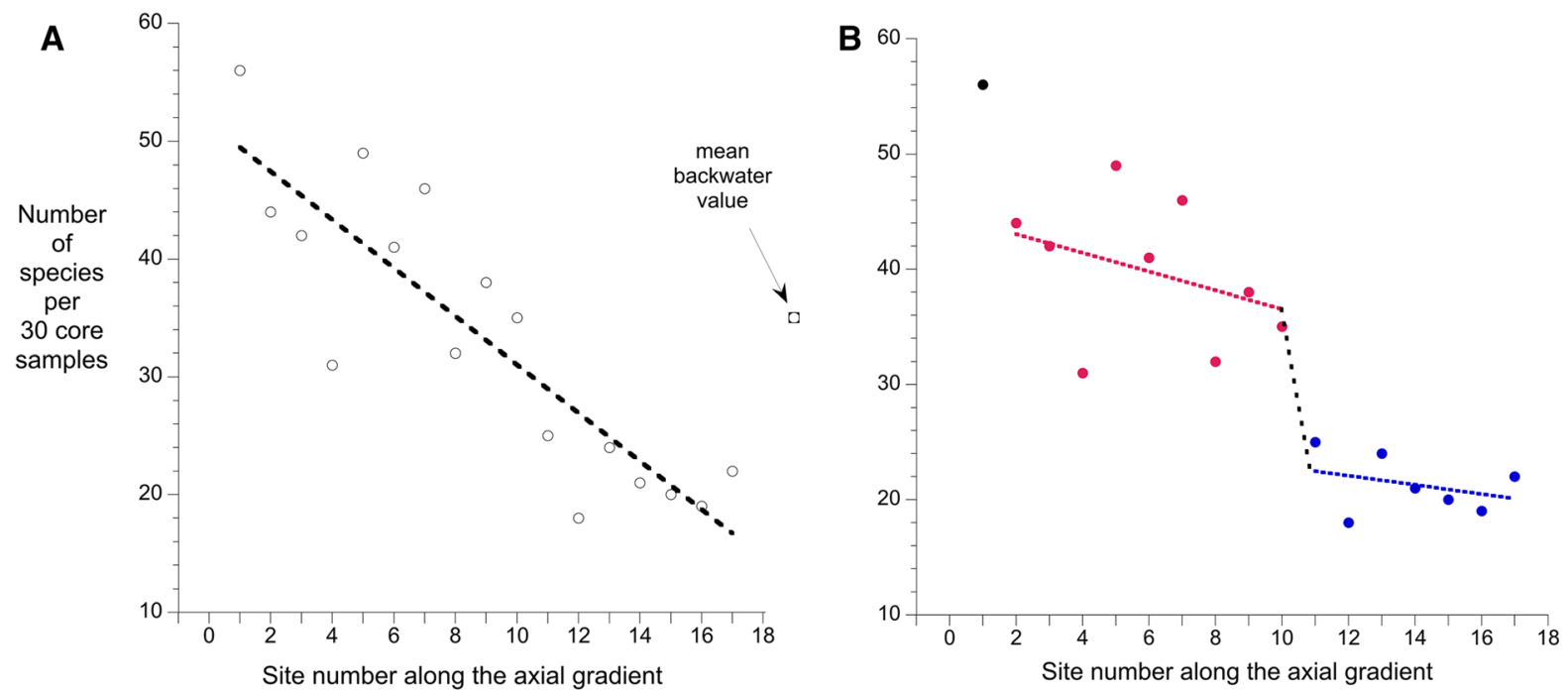

Fig. 7 Change in number of seagrass macrofaunal species along the longitudinal axis of the estuarine bay $\mathbf{a}$. Note in $\mathbf{b}$ the apparent break between sites 10 and 11, corresponding to the one in the same area shown by Barnes and Ellwood (2012)

by temporal shifts, but an individual survey of macrofaunal animals along the axial channel in 2012 showed an almost identical (and sharper) feature (Barnes and Ellwood 2012) in the same general location. Comparison of data across different spatial scales shows that decline upstream in number of species when assessed per site (Fig. 7) is greater than when assessed per region (Table 4): Clearly, the bay and lagoon + lower-estuary regions are large and, as also would be expected, the total fauna contained in each is considerably in excess of that at any individual site.

Assemblage abundance per unit area $\left(S_{\rho}=-0.35\right.$; $P=0.16$; Fig. 8a) and patchiness in assemblage abundance $\left(S_{\rho}=-0.20 ; P=0.45\right.$; Fig. $\left.8 \mathrm{~b}\right)$, however, showed no significant change with distance upstream; indeed, degree of patchiness along the axial gradient was significantly unchanging (Barnes 2019b). Neither 
Table 4 Biodiversity metrics of the various intertidal faunal regions of Knysna estuarine bay: Mao tau species density $\left(\mathrm{N}_{0}\right)$, with Chao 2 estimations; $\mathrm{N}_{1}$ and $\mathrm{N}_{2}$ species diversity; equitability of species abundance $(\mathrm{J})$; taxonomic diversity $(\Delta)$ and distinctness $\left(\Delta^{*}\right)$; and $\mathrm{N}_{2}$ functional diversity $\left(\mathrm{F}_{\mathrm{d}}\right)$ [with functional categories as per Macdonald et al. (2010) and Barnes and Hendy (2015a)]. Each axial regional metric is based on the common sample size of $180 \times 0.0054 \mathrm{~m}^{2}$ cores, yielding some $90 \%$ of the likely total species; backwaters metric based on $148 \times 0.0054 \mathrm{~m}^{2}$ samples. Peak values in bold

\begin{tabular}{llllll}
\hline & Mouth & Bay & Lagoon + lower estuary & Upper estuary & Backwaters \\
\hline Mao tau $\mathrm{N}_{0}$ density & 94 & 78 & 72 & 34 & 59 \\
Chao $2 \mathrm{~N}_{0}$ & $\mathbf{1 0 4}$ & 84 & 76 & 38 & 63 \\
$\mathrm{~N}_{1}$ diversity & 21.3 & $\mathbf{2 3 . 5}$ & 14.8 & 9.8 & 5.5 \\
$\mathrm{~N}_{2}$ diversity & 10.9 & $\mathbf{1 3 . 1}$ & 8.1 & 7.8 & 3.1 \\
J equitability & 0.68 & $\mathbf{0 . 7 3}$ & 0.61 & 0.65 & 0.42 \\
$\Delta$ diversity & 4.09 & $\mathbf{4 . 2 5}$ & 3.89 & 3.75 & 2.45 \\
$\Delta^{*}$ distinctness & 4.54 & 4.50 & $\mathbf{4 . 7 2}$ & 4.32 & 3.61 \\
$\mathrm{~F}_{\mathrm{d}}$ diversity & 7.56 & $\mathbf{8 . 3 8}$ & 5.13 & 4.77 & 1.64 \\
\hline
\end{tabular}

was there any significant relationship between number of species per site and overall assemblage abundance there $\left(S_{\rho}=0.43 ; P=0.08\right)$. However, significant relationships have been found between how patchy an individual species is and its occupancy and, to a lesser extent, its abundance: The more abundant and widespread the species, the less its patchiness, both in subtidal and in intertidal seagrass (Barnes 2019c, 2020), and both in interspecific comparisons (Barnes 2020) and intraspecifically (Barnes, in prep.) (Fig. 9). This suggests that the well-known macroecological abundance-occupancy pattern (e.g., He and Gaston 2003) can be extended into a patchinessabundance-occupancy one, at least in this habitat type. As can be seen in Fig. 9, the slopes of the power laws relating logit occupancy to log patchiness in individual species are much more variable than those interspecifically in the different faunal regions; thus, while the interspecific occupancy-patchiness slopes representing different regions do not differ (ANCOVA $F=1.3$, $P=0.3$ ), the equivalent intraspecific slopes are heterogeneous (ANCOVA $F=4.9, P<0.0001$ ) with a further six of the dominants (including the epifaunal Alaba and Cymadusa, and infaunal Caulleriella and Salmacoma) not showing significant occupancypatchiness relationships at all. This also indicates that disparate species together form assemblages with similar properties in the various regions. There were no discernable trends in either metric upstream, although the upper estuary did display the largest value of both $\beta$ and $\mathbf{R}^{2}$.

\section{General discussion and conclusions}

The most striking feature of the Knysna intertidal seagrass-associated macrobenthos is its relative spatial uniformity. Macrofaunal abundance does not vary markedly along the longitudinal axis, neither does patchiness of macrofaunal density. Number of species per unit area at a given site is a constant, while species density along whole sections of the gradient can be relatively uniform, and its fauna appears to form a single assemblage with only local variation in relative frequency of its dominant components. Even the subtidal fauna does not differ qualitatively from the intertidal one, although there are marked quantitative differences and overall it is much more abundant especially in the most marine-influenced regions where Alaba dominates (Barnes and Claassens 2020). Admittedly, being a marine-dominated system with under normal circumstances relatively little freshwater input (Day et al. 1951), for an estuarine system salinity is relatively constant; however, occasional episodes of severe freshwater flooding do occur once every 10-12 years or so, rendering most or all of the system temporarily fresh (see, e.g., Korringa 1956; Blake and Chimboza 2010). But, although sea water may penetrate far upstream and dominate most areas, there is much change along the Knysna axis in other features of direct relevance to macrobenthos, as in transitional paralic systems in general (Tagliapietra et al. 2012; Pérez-Ruzafa et al. 2019). Sediment changes from clean sand at the mouth, to soft organic mud in the lagoonal and lower estuarine regions, and 


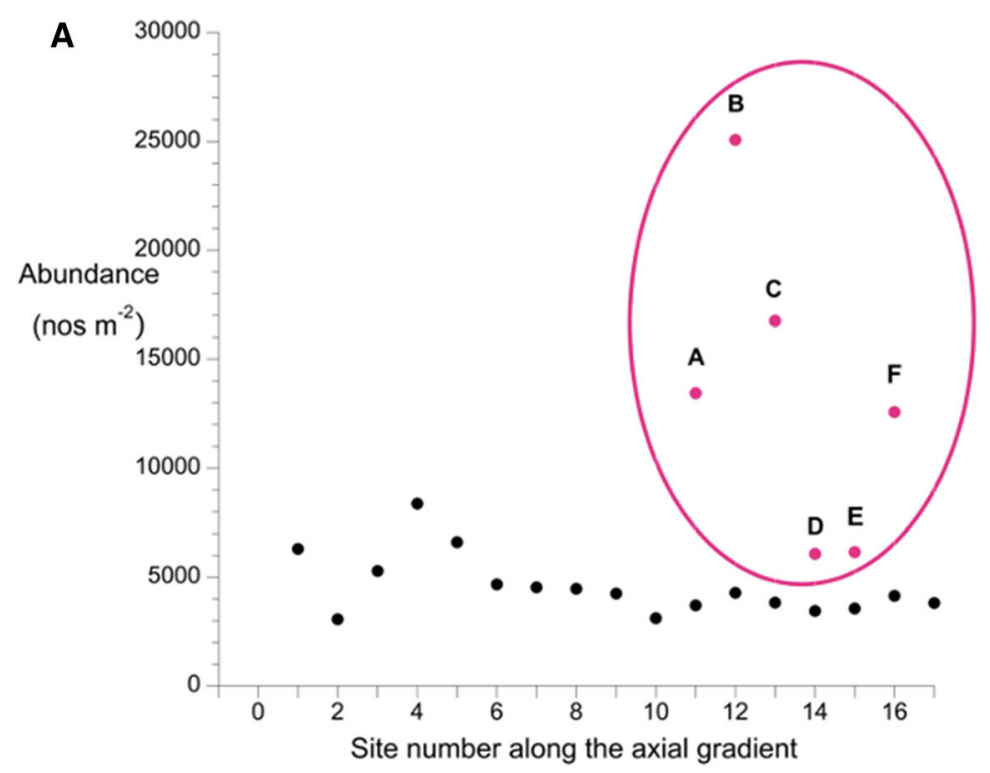

B

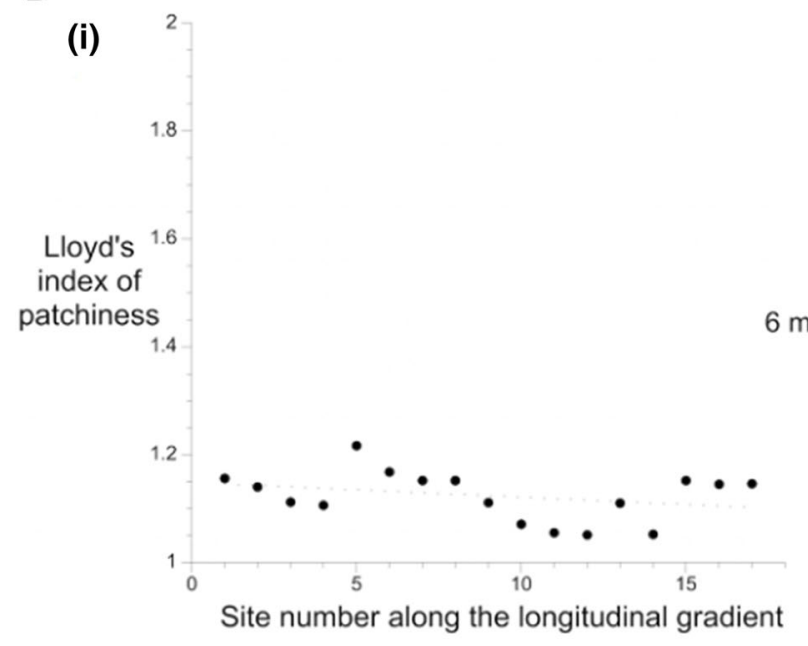

Fig. 8 Relative constancy of intertidal seagrass macrofaunal assemblage metrics along the longitudinal axis of the estuarine bay: a assemblage abundance, with an inset showing abundances at the six backwater-channel sites; and b(i) assemblage

to mud with admixed riverine gravel in the upper estuary (Day et al. 1951); shelter changes both as the estuary narrows and on transition from axial channel into backwater creeks (Day 1967); and shore profiles change from extensive tidal flats near the mouth to narrow steep slopes in the estuary supporting only linear strips of seagrass (Day 1967; Maree 2000). Rates of water exchange vary along the channel (Largier et al. 2000); characteristic density and shoot length of the eelgrass change with shore height and (ii)

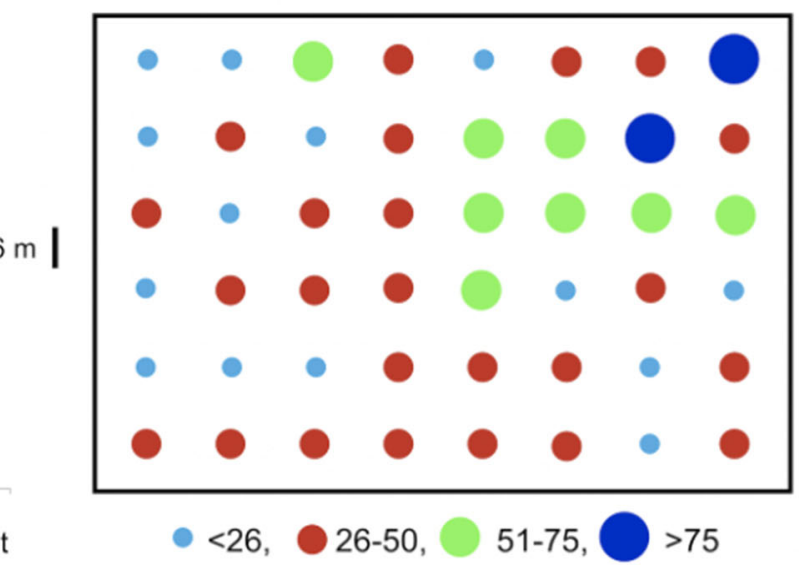

patchiness (data from Barnes 2019b). b(ii) illustrates spatial variation in macrofaunal density $0.01 \mathrm{~m}^{-2}$ across an area of site 2 (from data in Barnes 2016)

exposure (den Hartog 1970; Adams and Talbot 1992); and so on.

Being located at $34^{\circ} \mathrm{S}$, Knysna lies within the narrow mid-latitude belt recently identified by Whalen et al. (2020) as that displaying peak intensity of animal food consumption and hence potential top-down control of prey species. Like other South African estuarine areas supporting dwarf-eelgrass (Whitfield et al. 1989; Nel et al. 2018), it is a nursery area for many nektonic species (Whitfield and Kok 1992), 

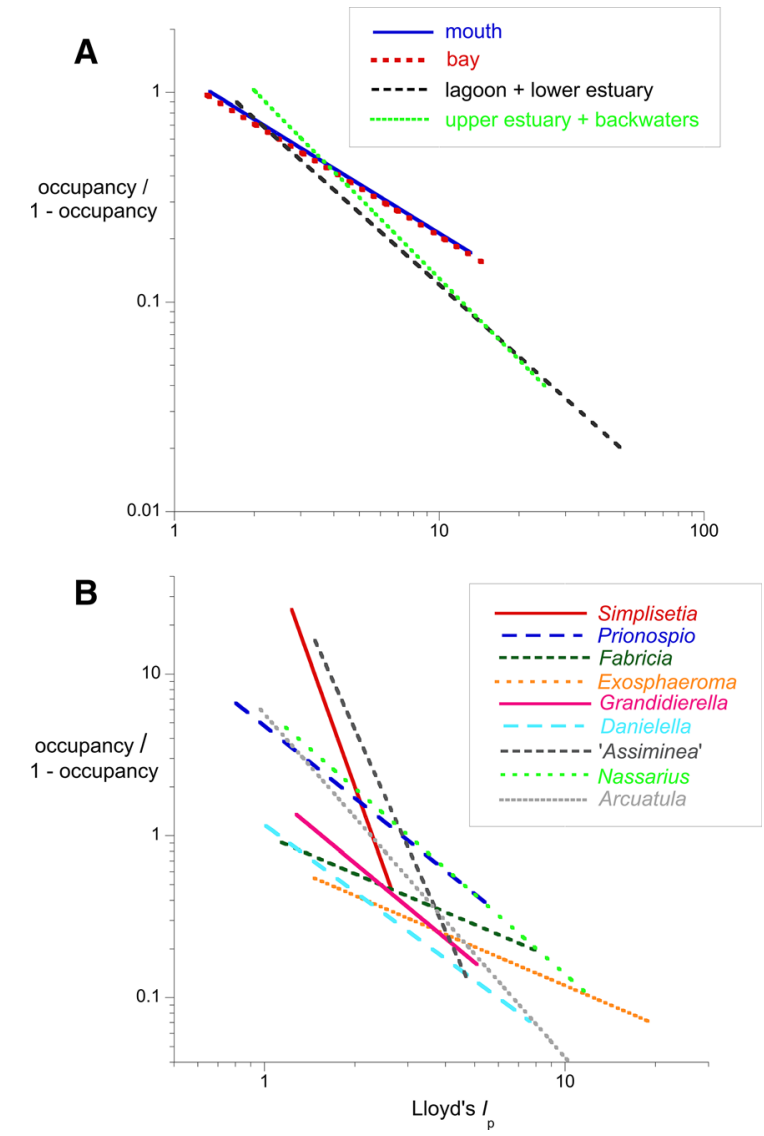

Fig. 9 The power laws $\left(y=\alpha x^{\beta}\right)$ describing significant relationships between log Lloyd's $I_{\mathrm{p}}$ patchiness and logit occupancy in the seagrass macrofauna of Knysna estuarine bay, both a interspecifically in the different assemblage types and $\mathbf{b}$ intraspecifically in individual dominant species

schools of juvenile fish being a common sight in its seagrass beds. Indeed, seagrass beds have been regarded as one the most important types of coastal nursery (Whitfield 2017; Lefcheck et al. 2019), both because of the food they provide (Whitfield 2017) and as refuge from larger fish predators (Whitfield 2020a). If, as is generally held to be the case in seagrass (Moksnes et al. 2008; Lewis and Anderson 2012; Duffey et al. 2015, etc.), the effect of this consumption, together with that exerted by adult fish (Pollard et al. 2017) and predatory members of the invertebrate macrobenthos, is top-down control of the seagrass microphytobenthic-biofilm consumers that dominate both epifauna and infauna, then many of features of
Knysna's seagrass macrobenthos become more understandable.

Three lines of evidence suggest that across the whole system seagrass macrofaunal abundance is below carrying capacity and not structured by densitydependent factors. First, the prevailing intertidal density along the longitudinal axis of some $4,000 \mathrm{~m}^{-2}$ is very low compared to the $>40,000 \mathrm{~m}^{2}$ animals occurring in similar intertidal dwarf-eelgrass beds in cool-temperate Europe (Blanchet et al. 2004; Barnes and Ellwood 2011; etc.) where predator rates are almost certainly lower on a fauna of similarly sized animals that are often members of the same families as represented at Knysna (Barnes and Hendy 2015b). Secondly, constancy of number of species per unit area, as demonstrated at the Kingfisher Creek site at Knysna (Barnes 2013b), is exactly what would be expected were the various species to be distributed independently of each other (granted their overall frequencies of occurrence) (Barnes and Barnes 2014b). Such independence of distribution is likely only if the whole assemblage is being maintained below the level at which species would otherwise interact. Thirdly, the large quantitative dataset of Barnes (2013b) from the same Kingfisher Creek site also showed that there were very few significant correlations $(0.5 \%)$ between the abundances of pairs of species and all those were very weak. Moreover, as seen elsewhere, for example within Pacific Canadian Zostera marina meadows (Stark et al. 2020), weak and very weak positive relationships greatly out-numbered negative ones, further suggesting the lack of competitive interspecific interactions. In such overall circumstances of low and unpredictable density of potential invertebrate prey species, predators could thus be expected to have to forage optimally (Beseres and Feller 2007) and to graze down local prey stocks to threshold levels before moving and repeating the process elsewhere, and having reduced their food stocks to low levels over wide areas could themselves then experience food limitation (Saulnier et al. 2000). The actions of such predators roaming widely over the surface might also help explain the uniform levels of macrofaunal patchiness characterizing large areas (Barnes and Hamylton 2019).

A second process that could help account for the observed features of the Knysna macrobenthic assemblages, and particularly their relative uniformity along the longitudinal axis, is if the presence of the seagrass 

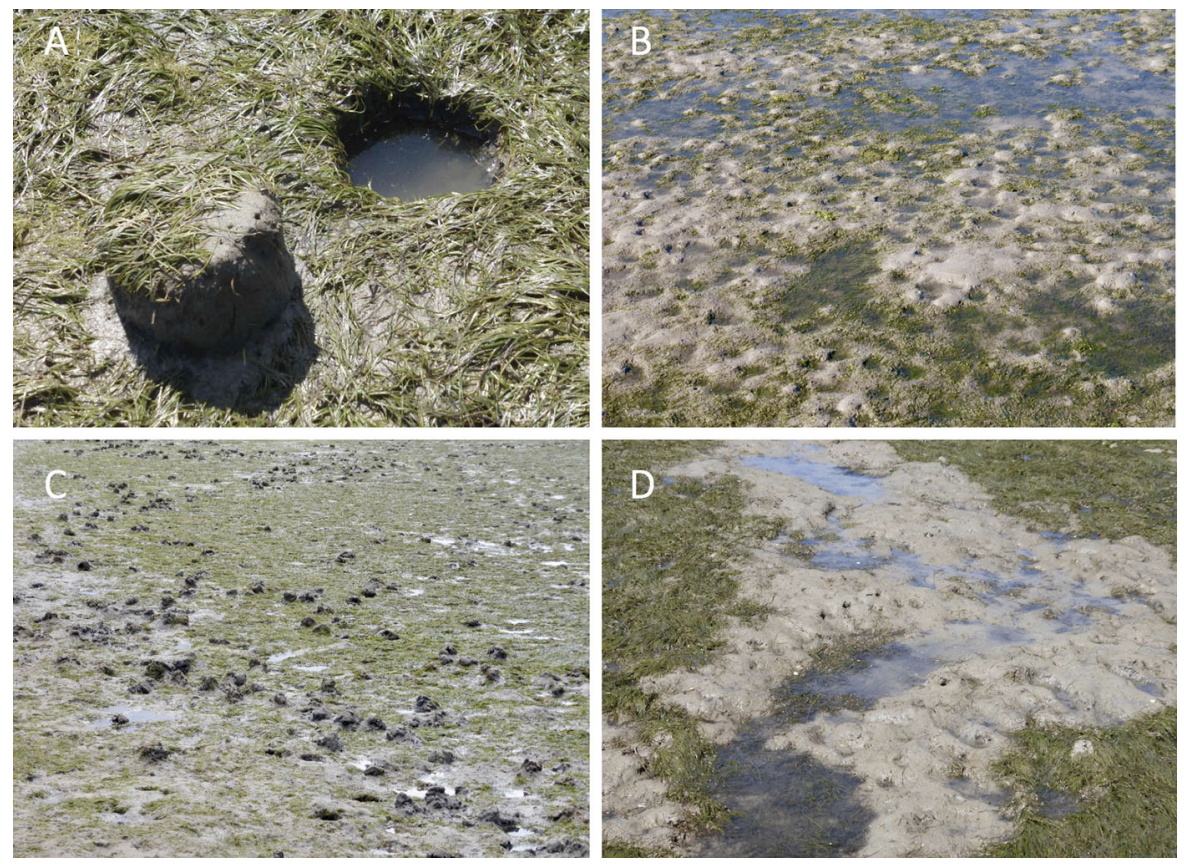

Fig. 10 Destructive effects of bait-collecting activities on intertidal seagrass habitat in the 'no-take bait sanctuary' section of the Knysna estuarine bay: a The hole and jettisoned plug created by pushing for mudprawn; $\mathbf{b}$, a substratum pock-marked

by such mudprawn pushing; and c, the resultant plugs scattered over the seagrass surface; $\mathbf{d}$, an area of seagrass destroyed by trenching for bait worms (from Barnes and Claassens 2020)

ameliorates variation in the local ambient microclimatic conditions, as a macro-algal cover has been shown to do (Scrosati 2017; Monteiro et al. 2017). Within the relatively uniform and stable conditions provided by the $Z$. capensis bed, species can penetrate upstream further than they might otherwise be able to do (Barnes and Ellwood 2012). Seagrass beds and other structurally complex systems (Hyman et al. 2019) generally appear to support macrofaunal assemblages that display spatial and temporal stability of abundance and composition, and high levels of resilience (Whanpetch et al. 2010; Blake et al. 2014; Gartner et al. 2015), and this may have important knock-on effects on the whole local coastal food web (Jankowska et al. 2019).

Granted the current high loss rates of seagrass throughout the world (Waycott et al. 2009; Short et al. 2011) and of Zostera capensis in southern Africa (Adams 2016), an important question is the implication of the operation of such potential structuring factors at Knysna for the future of its important seagrass system. Threats to the health of Knysna estuarine bay have recently been reviewed by

Claassens et al. (2020), and the two that might particularly affect the seagrass and its inhabitants are uncontrolled bait harvesting by destructive means and chlorophyte blooms. Bait harvesting by 'pushing' for mudprawns (Upogebia capensis) and trenching for worms (Marphysa, Polybrachiorhynchus and Arenicola spp.) is rife in Knysna (Simon et al. 2019), even (and arguably especially) in the formally protected bait-reserve area (Fig. 10) that also supports $79 \%$ of the estuarine bay's seagrass-associated species. Unfortunately, there are immense logistic and social problems associated with preventing illegal and restricting legal bait harvesting in southern Africa, especially in areas of high unemployment where subsistence fishing provides the main or only source of protein (Bandeira and Gell 2003; Napier et al. 2009) and the local intertidal provides the only source of bait (Barnes and Claassens 2020). Subsistence harvesting at Knysna is worth some ZAR $1 \times 10^{6}$ (Turpie 2007). Its precise effect on the seagrass macrofauna is unknown; however, basically because the extent of harvesting means that a like-with-like, harvested versus unharvested, comparison is not possible: No area of 
intertidal seagrass remains un-pushed or un-pumped. At other localities, however, it and the associated trampling are known to have severe consequences (e.g., Pillay et al. 2010; Garmendia et al. 2017; Short et al. 2011; Adams 2016). Nevertheless, the inherent resilience and spatial uniformity of the Knysna seagrass beds referred to above, together with the fact that they form one large interconnected system with dispersal possible between all sections, does offer hope.

In respect of the second major threat, at the moment the problems of eutrophication, to which Z. capensis is known to be sensitive (Mvungi and Pillay 2019), and consequent algal blooms are only local, affecting mainly the backwater channels into which the municipal sewage treatment plant discharges and in which there is a legacy of organic matter retention (Human et al. 2020). Knysna's large tidal prism proves invaluable insofar as minimizing blooms in the main axial channel is concerned. But the local effect of the chlorophyte blanket is dramatic and destructive. Animal numbers may increase on its seasonal dieback, except in the very local areas of anoxia, although this increase is almost entirely confined to densities of the dominant polychaete groups (except, for some reason, cirratulids) (Barnes 2019a). Crustaceans do not bounce back so readily, and as they provide the food for most fish in the nearby Swartvlei Estuary (Whitfield 1988, 2020b) and presumably therefore do so at Knysna, the fish populations may suffer the consequences: There is some evidence that this is indeed the case (Pollard et al. 2018). The chlorophyte problem is soluble (no pun intended) but at considerable cost (see Human et al. 2020). The financial reward, however, might also be large, not least because such blooms impact on tourism (Boesch et al. 1996) and tourists contribute some ZAR $1 \times 10^{9}$ per annum to the Knysna economy (Turpie 2007).

Knysna is perhaps not a typical South African estuary in being permanently open (see van Niekerk et al. 2020), without a significant presence of Kraussillichirus, and with a subtidal dominated by the littleknown Alaba pinnae, but nevertheless its fauna generally appears to be the classic Cape estuarine one (Day 1981; de Villiers et al. 1999); indeed, it supports $>40 \%$ of South African estuarine biodiversity. It also seems a microcosm of the country's estuarine problems, both environmental and socioeconomic, including loss of area to reclamation
(>30\% of the saltmarsh has already gone, and $25 \%$ of that remaining is under threat). Thus far, at least, it has managed to fare better than many other South African estuarine systems (van Niekerk et al. 2013), and it may yet continue to do so.

Acknowledgements I am most grateful to SANParks area office, Knysna, and SANParks Scientific Services, Rondevlei, for permission to conduct research on the Knysna system over the last decade or so; to Rhodes University Research Committee for their support; to my collaborators at various times, sequentially Farnon Ellwood, Morvan Barnes, Ian Hendy and Louw Claassens, for their contribution to the study; to Brian Allanson for his copious encouragement and support; and to an anonymous reviewer for saving me from error.

Author contributions RSKB conceived, designed, and executed this study and wrote the manuscript. No other person is entitled to authorship.

Funding No funding was received for conducting this study.

Data availability and material Datasets on which these analyses are based have been lodged in electronic format in the Rondevlei Office of SANParks Scientific Services (http:// dataknp.sanparks.org/sanparks/metacat/Nerinak.23.11/ sanparks) and are available on request.

\section{Compliance with ethical standards}

Conflict of interest The author declares no conflict of interest.

Consent for publication The author consents to publication.

Ethical approval All applicable international, national, and/ or institutional guidelines for sampling, care, and experimental use of organisms for the study were followed, and all necessary permissions and approvals were obtained in respect of the original collections of the data.

Open Access This article is licensed under a Creative Commons Attribution 4.0 International License, which permits use, sharing, adaptation, distribution and reproduction in any medium or format, as long as you give appropriate credit to the original author(s) and the source, provide a link to the Creative Commons licence, and indicate if changes were made. The images or other third party material in this article are included in the article's Creative Commons licence, unless indicated otherwise in a credit line to the material. If material is not included in the article's Creative Commons licence and your intended use is not permitted by statutory regulation or exceeds the permitted use, you will need to obtain permission directly from the copyright holder. To view a copy of this licence, visit http://creativecommons.org/licenses/by/4.0/. 


\section{References}

JB Adams 2016 Distribution and status of Zostera capensis in South African estuaries_a review S Afr J Bot 1076373 https://doi.org/10.1016/j.sajb.2016.07.007

Adams JB, Talbot MMB (1992) The influence of river impoundment on the estuarine seagrass Zostera capensis Setchell. Bot Mar 35: 69-75

PG Albano B Sabelli P Bouchet 2011 The challenge of small and rare species in marine biodiversity surveys: microgastropod diversity in a complex tropical coastal environment Biodivers Conserv 2032233237 https://doi.org/10.1007/ s10531-011-0117-x

BR Allanson LRD Human L Claassens 2016 Observations on the distribution and abundance of a green tide along an intertidal shore, Knysna Estuary S Afr J Bot 1074954 https://doi.org/10.1016/j.sajb.2016.02.197

AI Azovsky MV Chertoprood NV Kucheruk PV Rybnikov FV Sapozhnikov 2000 Fractal properties of spatial distribution of intertidal benthic communities Mar Biol 136581590 https://doi.org/10.1007/s002270050718

SO Bandeira F Gell 2003 The seagrasses of Mozambique and southeastern Africa EP Green FT Short Eds World Atlas of Seagrasses University of California Press Berkeley 93100

RSK Barnes 1989 What, if anything, is a brackish-water fauna? Earth Environ Sci Trans Roy Soc Edinb 80235240 https:// doi.org/10.1017/S0263593300028674

RSK Barnes 2013a Distribution patterns of macrobenthic biodiversity in the intertidal seagrass beds of an estuarine system, and their conservation significance Biodivers Conserv 22357372 https://doi.org/10.1007/s10531-0120414-z

RSK Barnes 2013b Spatial stability of macrobenthic seagrass biodiversity Mar Ecol Progr Ser 493127139 https://doi. org/10.3354/meps 10546

RSK Barnes 2016 Spatial homogeneity of benthic macrofaunal biodiversity across small spatial scales Mar Environ Res 122148157 https://doi.org/10.1016/j.marenvres.2016.10. 006

RSK Barnes 2017 Little-known and phylogenetically obscure South African estuarine microgastropods (Mollusca: Truncatelloidea) as living animals J Nat Hist 5787113 https://doi.org/10.1080/00222933.2017.1408867

RSK Barnes 2019a Context dependency in the effect of Ulvainduced loss of seagrass cover on estuarine macrobenthic abundance and biodiversity Aquat Conserv 29163174 https://doi.org/10.1002/AQC.2977

RSK Barnes 2019b Local patchiness of macrobenthic faunal abundance displays homogeneity across the disparate seagrass systems of an estuarine bay Mar Environ Res 148 99107 https://doi.org/10.1016/j.marenvres.2019.05.001

RSK Barnes 2019c Abundance/occupancy/patchiness relations in estuarine seagrass macrobenthos Estuar Coast Shelf Sci 228106360 https://doi.org/10.1016/j.ecss.2019.106360

RSK Barnes 2020 Interspecific relationship of patchiness to occupancy and abundance, as exemplified by seagrass macrobenthos Ecol Indic 121107083 https://doi.org/10. 1016/jecolind.2020.107083

RSK Barnes MKS Barnes 2014a Biodiversity differentials between the numerically-dominant macrobenthos of seagrass and adjacent unvegetated sand in the absence of sandflat bioturbation Mar Environ Res 993443 https://doi. org/10.1016/j.marenvres.2014.05.013

RSK Barnes MKS Barnes 2014b Spatial uniformity of biodiversity is inevitable if the available species are distributed independently of each other Mar Ecol Progr Ser 516263 266 https://doi.org/10.3354/meps 11067

RSK Barnes L Claassens 2020 Do beds of subtidal estuarine seagrass constitute a refuge for macrobenthic biodiversity threatened intertidally? Biodivers Conserv 2932273244 https://doi.org/10.1007/s10531-020-02019-0

RSK Barnes MDF Ellwood 2011 Macrobenthic assemblage structure in a cool-temperate intertidal dwarf-eelgrass bed in comparison to those in lower latitudes Biol J Linn Soc 104527540 https://doi.org/10.1111/j.1095-8312-2011. 01738.x

RSK Barnes MDF Ellwood 2012 Spatial variation in the macrobenthic assemblages of intertidal seagrass along the long axis of an estuary Estuar Coast Shelf Sci 112173182 https://doi.org/10.1016/j.ecss.2012.07.013

RSK Barnes SM Hamylton 2019 Isometric scaling of faunal patchiness: seagrass macrobenthic abundance across small spatial scales Mar Environ Res 14689100 https://doi.org/ 10.1016/j.marenvres.2019.03.011

RSK Barnes IW Hendy 2015a Seagrass-associated macrobenthic functional diversity and functional structure along an estuarine gradient Estuar Coast Shelf Sci 164233243 https://doi.org/10.1016/j.ecss.2015.07.050

RSK Barnes IW Hendy 2015b Functional uniformity underlies the common spatial structure of macrofaunal assemblages in intertidal seagrass beds Biol J Linn Soc 115114126 https://doi.org/10.1111/bij.12483

JJ Beseres RJ Feller 2007 Changes in the spatial distribution of subtidal macrobenthos due to predation by the white shrimp (Litopenaeus setiferus) Estuar Coast 30591600 https://doi.org/10.1007/BF02841956

RE Blake JE Duffy JP Richardson 2014 Patterns of seagrass community response to local shoreline development Estuar Coast 3715491561 https://doi.org/10.1007/s12237-0149784-7

Blake D, Chimboza N (2010) Sea Level Rise and Flood Risk Assessment for a Select Disaster Prone Area Along the Western Cape Coast. Phase 2 Report: Eden District Municipality Sea Level Rise and Flood Risk Modelling. Umvoto Africa (Pty) Ltd / Western Cape Department of Environmental Affairs and Development Planning. (https://www.westerncape.gov.za/eadp/files/atoms/files/ Eden\%20DM\%20SLR\%20Phase\%202\%20Modelling\% 20FInal_0.pdf)

H Blanchet X Montaudouin de A Lucas P Chardy 2004 Heterogeneity of macrozoobenthic assemblages within a Zostera noltii seagrass bed: diversity, abundance, biomass and structuring factors Estuar Coast Shelf Sci 61111123 https://doi.org/10.1016/j.ecss.2004.04.008

Boesch DF, Anderson DM, Horner RA, Shumway SE, Tester PA, Whitledge TE (1996) Harmful algal blooms in coastal waters: Options for prevention, control and mitigation. NOAA Coastal Ocean Program Decision Analysis Series No. 10. NOAA Coastal Ocean Office, Silver Spring MD

P Bouchet P Lozouet P Maestrati V Heros 2002 Assessing the magnitude of species richness in tropical marine 
environments: exceptionally high numbers of molluscs at a New Caledonia site Biol J Linn Soc 75421436 https://doi. org/10.1046/j.1095-8312.2002.00052.x

L Claassens RSK Barnes J Wasserman SJ Lamberth NAF Miranda L Niekerk van JB Adams 2020 Knysna estuary health: ecological status, threats and options for the future Afr J Aquat Sci $45 \quad 65 \quad 82$ https://doi.org/10.2989/ 16085914.2019.1672518

JA Coyer G Hoarau J Kuo A Tronholm J Veldsink JL Olsen 2013 Phylogeny and temporal divergence of the seagrass family Zosteraceae using one nuclear and three chloroplast loci Syst Biodivers 11271284 https://doi.org/10.1080/ 14772000.2013.821187

DS Moore WI Notz M Fligner 2018 The basic practice of statistics 8E Macmillan Gordonsville

JH Day 1959 The biology of Langebaan Lagoon: a study of the effect of shelter from wave action Trans R Soc S Afr 35475 547 https://doi.org/10.1080/00359195909519025

JH Day 1967 Biology of the Knysna Estuary, South Africa GF Lauff Eds Estuaries American Association for the Advancement of Science Washington 397407

JH Day NAH Millard AD Harrison 1951 The ecology of South African estuaries. Part III. Knysna: a clear open estuary Trans R Soc S Afr 33367413 https://doi.org/10.1080/ 00359195109519891

MN Dethier GC Schoch 2006 Taxonomic sufficiency in distinguishing natural spatial patterns on an estuarine shoreline Mar Ecol Progr Ser 3064149 https://doi.org/10.3354/ meps306041

JE Duffy PL Reynolds C Boström JJ Stachowicz 2015 Biodiversity mediates top-down control in eelgrass ecosystems: a global comparative experimental approach Ecol Lett 18 696705 https://doi.org/10.1111/ele.12448

FL Forcino LR Leighton P Twerdy JF Cahill 2015 Reexamining sample size requirements for multivariate, abundancebased research: When resources are limited, the research does not have to be PLoS ONE 106 e0128379 https://doi. org/10.1371/journal.pone.0128379

GBIF (2020) Global Species Diversity Information Facility: Cornirostra Ponder, 1990. https://www.gbif.org/ occurrences/1101139915, and Sayella Dall, 1885. https:// www.gbif.org/occurrences/2298827. Accessed 1 Nov 2020

Garmendia JM, Valle M, Borja Á, Chust G, Lee DJ, Rodríguez JG, Franco J (2017) Effect of trampling and digging from shellfishing on Zostera noltei (Zosteraceae) intertidal seagrass beds. Sci Mar 81: 121-128 https://doi.org/10.3989/ scimar.04482.17A

A Gartner PS Lavery H Lonzano-Montes 2015 Trophic implications and faunal resilience following one-off and successive disturbances to an Amphibolis griffithii seagrass system Mar Poll Bull 94131143 https://doi.org/10.1016/j. marpolbul.2015.03.001

TG Gerwing K Cox AM Allen Gerwing L Campbell T Macdonald SE Dudas F Juanes 2020 Varying intertidal invertebrate taxonomic resolution does not influence ecological findings Estuar Coast Shelf Sci 232106516 https://doi.org/ 10.1016/j.ecss.2019.106516

NJ Gotelli RK Colwell 2001 Quantifying biodiversity: procedures and pitfalls in the measurement and comparison of species richness Ecol Lett 4379391 https://doi.org/10. 1046/j.1461-0248.2001.00230.x

CL Griffiths TB Robinson A Mead 2009 The status and distribution of marine alien species in South Africa G Rilov JA Crooks Eds Biological invasions in marine ecosystems Springer Berlin

Grindley JR (1985) Estuaries of the Cape, Part II Synopses of Available Information on individual Systems No. 30 Knysna. CSIR, Stellenbosch.

Ø Hammer DAT Harper PD Ryan 2019 PAST: Paleontological statistics software package for education and data analysis Version 324

C Hartog den 1970 The sea-grasses of the world North Holland Amsterdam

F He KJ Gaston 2003 Occupancy, spatial variance and the abundance of species Am Nat 162366375 https://doi.org/ $10.1086 / 377190$

R Hershler GM Davis 1980 The morphology of Hydrobia truncata (Gastropoda: Hydrobiidae): relevance to systematics of Hydrobia Biol Bull 158195219 https://doi.org/10. 2307/1540931

AN Hodgson J Dickens 2012 Activity of the mangrove snail Cerithidea decollata (Gastropoda: Potamididae) in a warm temperate South African estuary Estuar Coast Shelf Sci 10998106 https://doi.org/10.1016/j.ecss.2012.05.033

Hodgson AN, Allanson BR (eds) (2000) The Knysna Basin Project, 1995-1998. A scientific report on the Knysna Estuary. Trans Roy Soc S Afr 55(2): 97-240.

LRD Human JB Adams BR Allanson 2016 Insights into the cause of an Ulva lactuca Linnaeus bloom in the Knysna Estuary S Afr J Bot 175562 https://doi.org/10.1016/j.sajb. 2016.05.016

LRD Human R Weitz BR Allanson JB Adams 2020 Nutrient fluxes from sediments pose management challenges for the Knysna Estuary, South Africa Afr J Aquat Sci 4519 https://doi.org/10.2989/16085914.2019.1671787

AC Hyman TK Frazer CA Jacoby JR Frost M Kowalewski 2019 Long-term persistence of structured habitats: seagrass meadow as enduring hotspots of biodiversity and faunal stability Proc Roy Soc B 286201901861 https://doi.org/10. 1098/rspb.2019.1861

JH Day Eds 1981 Estuarine Ecology with particular reference to southern Africa Balkema Rotterdam

E Jankowska LN Michel G Lepoint M Wlodarska-Kowalczuk 2019 Stabilizing effects of seagrass meadows on coastal water benthic food webs J Exp Mar Biol Ecol 5105463 https://doi.org/10.1016/j.jembe.2018.10.004

P Korringa 1956 Oyster culture in South Africa Hydrological, biological and ostreological observations in the Knysna Lagoon, with notes on conditions in other South African waters Invest Rep Div Sea Fish S Afr 2085

JL Largier C Attwood J-L Harcourt-Baldwin 2000 The hydrographic character of the Knysna Estuary Trans R Soc S Afr 55107122 https://doi.org/10.1080/00359190009520437

JS Lefcheck BB Hughes AJ Johnson BW Pfirrman DB Rasher AR Smyth BL Williams MW Beck RJ Orth 2019 Are coastal habitats important nurseries? A Meta-Anal Conserv Lett 12 e12645 https://doi.org/10.1111/conl.12645

LS Lewis TW Anderson 2012 Top-down control of epifauna by fishes enhances seagrass production Ecology 9327462757 https://doi.org/10.1890/12-0038.1 
M Lloyd 1967 Mean crowding J Anim Ecol 36130 https://doi. org/10.2307/3012

MA Hemminga CM Duarte 2000 Seagrass ecology Cambridge University Press Cambridge

TA Macdonald BJ Burd VI Macdonald A Roodeselaar van 2010 Taxonomic and feeding guild classification for the marine benthic macroinvertebrates of the Strait of Georgia, British Columbia Can Tech Rep Fish Aquat Sci 287463

B Maree 2000 Structure and status of the intertidal wetlands of the Knysna Estuary Trans Roy Soc S Afr 55163176 https://doi.org/10.1080/00359190009520441

MI McCormick 1998 Ontogeny of diet shifts by a microcarnivorous fish, Cheilodactylus spectabilis: relationship between feeding mechanics, microhabitat selection and growth Mar Biol 132920 https://doi.org/10.1007/ s002270050367

A Mead JT Carlton CL Griffiths M Rius 2011 Revealing the scale of marine bioinvasions in developing regions: a South African re-assessment Biol Invasions 1319912008 https:// doi.org/10.1007/s10530-011-0016-9

P-O Moksnes M Gullström K Tryman S Baden 2008 Trophic cascades in a temperate seagrass community Oikos 117 763777 https://doi.org/10.1111/j.0030-1299.2008.16521. $\mathrm{x}$

C Monteiro GI Zardi CD McQuaid EA Serrão GA Pearson KR Nicastro 2017 Canopy microclimate modification in central and marginal populations of a marine macroalga Mar Biodivers 49415424 https://doi.org/10.1007/s12526-0170824-y

CE Murphy RJ Orth JS Lefcheck 2021 Habitat primarily structures seagrass epifaunal communities: a regional-scale assessment in the Chesapeake Bay Estuar Coast 44442452 https://doi.org/10.1007/s12237-020-00864-4

EF Mvungi D Pillay 2019 Eutrophication overrides warming as a stressor for a temperate African seagrass (Zostera capensis) PLoS ONE 144 e0215129 https://doi.org/10. 1371/journal.pone.0215129

VR Napier JK Turpie BM Clark 2009 Value and management of the subsistence fishery at Knysna Estuary, South Africa Afr J Mar Sci 31297310 https://doi.org/10.2989/AJMS.2009. 31.3.3.991

L Nel NA Strydom JB Adams 2018 Habitat partitioning in juvenile fishes associated with three vegetation types in selected warm temperate estuaries, South Africa Environ Biol Fish 10111371148 https://doi.org/10.1007/s10641018-0762-y

L Niekerk van JB Adams GC Bate TH Wooldridge 2013 Country-wide assessment of estuary health: An approach for integrating pressures and ecosystem response in a data limited environment Estuar Coast Shelf Sci 130239251 https://doi.org/10.1016/j.ecss.2013.05.006

L Niekerk van JB Adams NC James SJ Lamberth CF MacKay JK Turpie A Rajkaran SP Weerts AK Whitfield 2020 An estuary ecosystem classification that encompasses biogeography and a high diversity of types in support of protection and management S Afr J Aquat Sci 45199216 https://doi.org/10.2989/16085914.2019.1685934

SI Passy 2016 Abundance inequality in freshwater communities has an ecological origin Amer Nat 187505516 https://doi. org/10.1086/685424
N Peer NAF Miranda R Perissinotto 2015 A review of fiddler crabs (genus $U c a$ Leach, 1814) in South Africa Afr Zool 50 187204 https://doi.org/10.1080/15627020.2015.1055700

D Pillay GM Branch J Dawson D Henry 2011 Contrasting effects of ecosystem engineering by the cordgrass Spartina maritima and the sandprawn Callianassa kraussi in a marine-dominated lagoon Estuar Coast Shelf Sci 91169 176 https://doi.org/10.1016/j.ecss.2010.10.010

D Pillay GM Branch CL Griffiths C Williams 2010 Ecosystem change in a South African marine reserve (1960-2009): role of seagrass loss and anthropogenic disturbance Mar Ecol Progr Ser 4153548 https://doi.org/10.3354/ meps08733

M Pollard AN Hodgson HM Kok AK Whitfield 2017 Eelgrass beds and bare substrata - sparid and mugilid composition in contrasting littoral estuarine habitats Afr J Mar Sci 39211 224 https://doi.org/10.2989/1814232X.2017.1333043

M Pollard AK Whitfield AN Hodgson 2018 Possible influences of a macroalgal bloom in eelgrass beds on fish assemblages in the lower Knysna Estuary, South Africa Afr J Aquat Sci $43 \quad 319323$ https://doi.org/10.2989/16085914.2018. 1515063

A Pérez-Ruzafa F Pascalis De M Ghezzo JI Quispe-Becerra MI Hernández-García C Vergara IM Pérez-Ruzafa G Umgiesser C Marcos 2019 Connectivity between coastal lagoons and sea: Asymmetrical effects on assemblages' and populations' structure Estuar Coast Shelf Sci 216171 186 https://doi.org/10.1016/j.ecss.2018.02.031

PL Reynolds JJ Stachowicz K Hovel JE Duffy 2018 Latitude, temperature, and habitat complexity predict predation pressure in eelgrass beds across the Northern Hemisphere Ecology 992935 https://doi.org/10.1002/ecy.2064

TB Robinson CL Griffiths CD McQuaid M Rius 2005 Marine alien species of South Africa - status and impacts Afr J Mar Sci 27297306 https://doi.org/10.2989/ 18142320509504088

Russell IA, Randall RM, Kruger N (2012) Garden Route National Park, Knysna Coastal Section, State of Knowledge. SANParks Scientific Services, Rondevlei (available at http://www.sanparks.org/docs/conservation/scientific/ coastal/knla-may2012.pdf)

E Saulnier H Bris Le A Tableau JC Dauvin A Brind'Amour 2020 Food limitation of juvenile marine fish in a coastal and estuarine nursery Est Coast Shelf Sci 241106670 https://doi.org/10.1016/j.ecss.2020.106670

RA Scrosati 2017 Community-level facilitation by macroalgal foundation species peaks at an intermediate level of environmental stress Algae 324146 https://doi.org/10.4490/ algae.2017.32.2.20

FT Short B Polidoro SR Livingstone JC Zieman 2011 Extinction risk assessment of the world's seagrass species Biol Conserv 14419611971 https://doi.org/10.1016/j.biocon.2011. 04.010

C Simon AN Toit du MKS Smith L Claassens F Smith P Smith 2019 Bait collecting by subsistence and recreational fishers in Knysna Estuary may impact management and conservation Afr Zool $5491 \quad 103$ https://doi.org/10.1080/ 15627020.2019.1608862

KA Stark PL Thompson J Yakimishyn L Lee EM Adamczyk M Hessing-Lewis MI OConnor 2020 Beyond a single patch: local and regional processes explain diversity patterns in a 
seagrass epifaunal community Mar Ecol Progr Ser 65591 106 https://doi.org/10.3354/meps 13527

D Tagliapietra M Sigovini P Magni 2012 Saprobity: a unified view of benthic succession models for coastal lagoons Hydrobiologia 6861528 https://doi.org/10.1007/s10750012-1001-8

Turpie J (2007) Cape Action for People and the Environment (C.A.P.E.) Estuarine Management Guideline 9: Maximising the economic value of estuaries. Anchor Environmental Consultants, Cape Town. (Available at https://www. overstrand.gov.za/en/documents/town-planning/ legislation/national-environmental-managementintegrated-coastal-management-act-24-of-2008/1281-no9-guideline-economic-value-oct-2007/file).

Turpie J, Clark B (2007) Development of a conservation plan for temperate South African estuaries on the basis of biodiversity importance, ecosystem health and economic costs and benefits. Final Report. Anchor Environmental Consultants / C.A.P.E. Regional Estuarine Management Programme, Cape Town. (Available at https:// anchorenvironmental.co.za/sites/default/files/2017-11/ Cape \%20Estuaries\%20Cons\%20Plan\%20Final\% 20Report.pdf).

C Villiers de A Hodgson A Forbes 1999 Studies on estuarine macroinvertebrates B Allanson D Baird Eds Estuaries of South Africa Cambridge University Press Cambridge

MR Vinson MA Baker 2008 Poor growth of rainbow trout fed New Zealand mud snails Potamopyrgus antipodarum N Amer J Fish Manag 28701708 https://doi.org/10.1577/ M06-039.1

J Wasserman L Claassens JB Adams 2020 Mapping subtidal estuarine habitats with a remotely operated underwater vehicle (ROV) Afr J Mar Sci 42123128 https://doi.org/10. 2989/1814232X.2020.1731598

M Waycott CM Duarte TJB Carruthers SL Williams 2009 Accelerating loss of seagrasses across the globe threatens coastal ecosystems Proc Natl Acad Sci USA 10612377 12381 https://doi.org/10.1073/pnas.0905620106

MA Whalen RDB Whippo JJ Stachowicz JE Duffy 2020 Climate drives the geography of marine consumption by changing predator communities P Natl Acad Sci USA 117 2816028166 https://doi.org/10.1073/pnas.2005255117

N Whanpetch M Nakaoka H Mukai T Suzuki S Nojima T Kawai C Aryuthaka 2010 Temporal changes in benthic communities of seagrass beds impacted by a tsunami in the
Andaman Sea, Thailand Estuar Coast Shelf Sci 87246252 https://doi.org/10.1016/j.ecss.2010.01.001

AK Whitfield 1988 The fish community of the Swartvlei estuary and the influence of food availability on resource utilization Estuaries 11160170 https://doi.org/10.2307/1351968

AK Whitfield 2017 The role of seagrass meadows, mangrove forests, salt marshes and reed beds as nursery areas and food sources for fishes in estuaries Rev Fish Biol Fish 2775 110 https://doi.org/10.1007/s11160-016-9454-x

AK Whitfield 2020a Littoral habitats as major nursery areas for fish species in estuaries: a reinforcement of the reduced predation paradigm Mar Ecol Progr Ser 649219234

AK Whitfield 2020b Fish food webs in a South African estuary: a spatial and temporal assessment Environ Biol Fish https://doi.org/10.1007/s10641-020-01042-y,inpress

AK Whitfield LE Beckley BA Bennett GM Branch HM Kok IC Potter RP Elst van der 1989 Composition, species richness and similarity of ichthyofaunas in eelgrass Zostera capensis beds of southern Africa S Afr J Mar Sci 8251259 https://doi.org/10.2989/02577618909504565

AK Whitfield SJM Blaber 1978 Resource segregation among iliophagous fish in Lake St Lucia, Zululand Environ Biol Fish 3293296 https://doi.org/10.1007/BF00001455

AK Whitfield HM Kok 1992 Recruitment of juvenile marine fishes into permanently open and seasonally open estuarine systems on the southern coast of South Africa Ichthyol Bull JLB Smith Inst 57139

Whitfield AK, Baliwe NG (2013) A century of science in South African estuaries: Bibliography and review of research trends. South African Network for Coastal and Oceanic Research Occasional Report No. 7:1-289.

RH Whittaker 1972 Evolution and measurement of species diversity Science 147250260 https://doi.org/10.2307/ 1218190

van Niekerk L, Adams JB, Lamberth SJ, MacKay CF, Taljaard S, Turpie JK, Weerts SP, Raimondo DC (eds) (2019) South African National Biodiversity Assessment 2018: Technical Report. Volume 3: Estuarine Realm. South African National Biodiversity Institute, Pretoria, Report SANBI/ NAT/NBA2018/Vol3/A.

Publisher's Note Springer Nature remains neutral with regard to jurisdictional claims in published maps and institutional affiliations. 